\title{
The Impact of the Trans-Sumatran Highway Development on Logistic Cost Efficiency
}

\author{
Reslyana Dwitasari ${ }^{1}$, Yandra Rahadian Perdana ${ }^{2}$, Yessi Gusleni ${ }^{1}$, and Zusnita Meyrawati ${ }^{3}$ \\ ${ }^{1}$ Resarch and Development Center for Multimodal Transport, Kementrian Perhubungan, Indonesia, \\ ${ }^{2}$ Department of Industrial Engineering, Universitas Islam Negeri Sunan Kalijaga, Indonesia \\ ${ }^{3}$ Greater Jakarta Transportation Authority, Kementrian Perhubungan, Indonesia \\ e-mail: reslyana.dwitasari@dephub.go.id
}

\begin{abstract}
The development of transport infrastructures of the Trans-Sumatran Highway is the policy of the Indonesian government to boost the economic growth. However, on the other hand, this idea needs to be proven since Indonesia has unique regional characteristics in terms of natural, social, and cultural conditions that bring impacts on congestion, low levels of travel security, and illegal costs or surcharges. This problem triggers inefficient logistics activities which can be seen from the high costs of shipping, transportation, and administrative. Therefore, this paper aims to examine the impact of the TransSumatran Highway construction on logistics cost. The result of this study indicates that there are several benefits obtained from the toll road development. For the manufacturers, they may get a faster shipping process so that inventory turnover is getting higher. High inventory turnover can make inventory costs lower. While for the transporters, faster travel times and smooth toll road conditions can reduce the costs of vehicle maintenance and fuel. In addition, the toll road is able to eliminate the surcharges that previously often arise on trips between Lampung and Palembang. This paper argues that the Trans-Sumatra Highway can enhance the transportation and logistics activities.
\end{abstract}

Keywords-Highway, Transportation, Logistics Cost.

\section{I.INTRODUCTION}

$\mathrm{T}$ RANSPORT infrastructure becomes a proxy for logistics performance, where inefficient logistics performance can weaken the economic performance [1]. The decline in economic performance can be indicated through high logistics costs as a result of low logistics performance [2]. Logistics has become one of the most important fields affecting economic growth [3]. In the context of transportation, logistics activities must be supported by infrastructure availability, such as roads. Infrastructure has a positive contribution to the factors of productivity, connectivity, and accessibility [4]. Logistics become an essential part for the process of accelerating economic growth. Efficient logistics is an important determinant of a country's competitiveness [5]. Logistics performance statistically has positive and significant correlation with exports and imports [6]. Sezer and Abasiz (2017) explain that logistics is one of the tools that play an important role in the change and improvement of economic indicators. Developing countries need to continue to improve the quality of infrastructure to generate better economic growth [7]. Logistics and transportation increasingly play an important role in international trade relations. This is evident that logistics performance can bring about significant growth in a country's trade flows. There is a relationship between logistics costs and Gross Domestic Products (GDP) [8]. The trends of logistics costs show that the lower the logistics costs of a country are likely to result in higher GDP.

Contextually, developments in the transport infrastructure sector is of concern to the Indonesian government today. One of them is the development of the Trans-Sumatran Highway section connecting Lampung and Palembang. The hypothesis with toll road construction is the positive impact received on the economic sector. However, on the other hand, this hypothesis needs to be proven because there are social and cultural factors influencing the behavior of the communities or consumers as the highway users Indonesia has unique regional characteristics in terms of natural, social, and cultural conditions that bring impacts on congestion, low levels of travel security, and illegal costs. This issue drives inefficient logistics activities which can be indicated by the high costs of shipping, transportation, and inventory. Therefore, this paper aims to investigate the impact of the construction of the Trans-Sumatran Highway on logistics costs.

This paper consists of five sections. The purpose of this paper is explained in section one. A description of the literature on infrastructure and logistics costs can be found in section two. Next, the method of this paper is elaborated in section three. Subsequently, the results of the study and discussion are described in section four. Finally, conclusions and recommendations are placed in section five.

\section{II.LITERATURE REVIEW}

Road infrastructure plays an important role in supporting not only the movement of people and goods but also the flow of money within an island and/or inter-island. The development of road infrastructure aims at improving the mobility smoothness of the whole entities, it links production locations to consumers [9]. In the economic context, infrastructure is useful to help producers get raw materials from suppliers and distribute products to consumers more effectively and efficiently. There are aspects of ease and affordability with the presence of infrastructure [10]. Economic activity is a derivative of various processes that involve suppliers, producers, distributors, and consumers [11]. This process illustrates the linkages between actors in a network known as supply chains. Referring to the supply chain context, road infrastructure becomes one of the sub-systems that can support the creation of effectiveness and efficiency in trading activities [12].

Production and consumption activities cannot rule out the importance of access. Road infrastructure provides access for producers to freely distribute their products and ease consumers to obtain them. The obstacle which is frequently experienced by consumers is the scarcity of products caused 
by distribution constraints [13]. Products that consumers actually need are available, but producers are not able to deliver them optimally resulting in product scarcity [14]. Therefore, it is inevitable that the presence of infrastructure has a significant effect on economic activity. It shows that the gap between supply and demand in the market is caused by the lack of quantity and quality of infrastructure [15]. On the other hand, this gap leads to the high price of commodities attained by consumers. The rationale is that consumers must bear high costs from producers, where producers charge transportation and inventory costs to consumers [16]. When distribution access is complex, the situation that occurs is that the producer has to pay higher trucking cost, fuel cost, and driver. Then, the slow delivery process makes inventory turnover slow so that inventory costs are getting higher as well. Thus, the existence of road infrastructure becomes a lever to generate more effective and efficient logistics activities [8].

\section{III.METHOD}

This paper implements a qualitative approach to gain a picture of the effect of the development of the TransSumatran Highway on logistics costs. Variables used to measure logistics costs are transportation costs, inventory costs, and administrative costs. The impact is measured based on the views of 46 respondents, i.e.: six respondents from the Indonesian Logistics and Forwarders Association, six respondents from the Indonesian Trucking Association, two producers/manufacturers, three people from the Local Government, and 30 truck drivers. This paper discusses the level of costs incurred in the presence of highway and before the construction. This process identifies activities that cause costs. From the identification, it is obtained a model that describes the arouse costs in the commodity supply chain.

\section{IV.RESULTS AND DISCUSSION}

The result of data collection from 30 truck drivers shows that $70 \%$ of truck drivers choose to use the highway for shipping the goods and 30\% choose to use the non-toll road. The reasons for choosing the highway is that it offers faster and more efficient travel time, more safety and security, and more frequency of goods delivery. The majority of route selections are based on truck driver decisions, but in contrast to manufacturers who have contracted their goods shipments through freight transport service providers, the route selection is defined based on the manufacturer's will and in accordance with agreements/contracts between the transport companies. The development of the Trans-Sumatran Highway has a positive impact on the delivery time. Based on field observations, it indicates that the goods shipment can save $50 \%-70 \%$ on delivery time.

Meanwhile, the survey result reveals that the majority of logistics operators choose the the Trans-Sumatran Highway due to fuel cost efficiency. Based on the interview result, opting the highway route can save $15.7 \%$ fuel expenditure. In addition, efficiency is also obtained from the loss of surcharges. In general, the presence of the highway connecting Lampung and Palembang has a positive impact on transport activities involving businesses (producers, truck owners, and consumers). There is a significant improvement affected by the construction of Trans-Sumatran Highway.
Before the construction of the highway, the travel time between Bakauheni Port required an average of 12 hours. The presence of the highway is able to reduce travel time up to 3 - 4 hours from Bakauheni Port to Palembang and vice versa. This provides timeliness for businesses, such as producers, logistics service providers, and consumers.

Other positive impacts are also felt by producers and transporters. For producers, the presence of the toll roads provides better punctuality. This has an effect on the accuracy of inventory and distribution planning. With the toll road, producers can send their products faster so inventory turnover becomes higher. High inventory turnover can make inventory costs lower. In addition, the manufacturer's marketing department can provide consumers with more certainty regarding delivery time. Then, for transporters, faster travel time and smooth toll road conditions can reduce vehicle maintenance and fuel costs. Technically, truck engines can work efficiently which result in lower vehicle maintenance and fuel costs. In addition, the existence of the toll road is able to eliminate illegal levies that previously often occur on trips between Lampung and Palembang. There is a shift in the illegal cost to toll road charge, which results in a decrease in transport cost. The existence of the toll road for consumers is the punctuality of the receipts of products or commodities sent by producers. From the results of observing the movement pattern of freight transport in Lampung, there are two transshipment points connected to the Trans-Sumatran Highway, namely Bakauheni Port and Panjang Port. However, the toll road has not been connected directly to the Panjang port. It makes the distribution activities from the production location to the Panjang Port ineffective and inefficient. Panjang Port and the toll road are still unlinked approximately 8-10 km. Yet, connectivity is the key so that the existence of the highway has an impact on logistics costs.

The presence of infrastructure has an important role for a country or region to increase economic growth. Infrastructure has become the driving force of economic activities. Thus, investment of infrastructure becomes the lever of trade transactions. Basically, trade is a transaction process between seller and buyer which is facilitated by infrastructures. Sellers and buyers represent supply and demand, where this process involves logistical activities. By definition, logistics is the planning and control of the flow of information, goods, and finance involving suppliers, producers, distributors, and end consumers. Logistics activities have an important standing in trade transactions. Efficient and optimal logistics activities will have a positive effects on the economic growth of a region. This paper shows that infrastructure and logistics have an interrelated role, whereby infrastructure can increase logistics capacity and efficiency, also create value-added services. This condition induces lower logistics costs, shorter delivery time, and more opportunities for work expansion. The implications of this process are expected to be able to improve efficiency and economic growth.

\section{V.CONCLUSION AND FUTURE RESEARCH}

The Trans-Sumatera Highway linking Lampung and Palembang delivers positive impacts on transportation and logistics. For producers, they can send their products faster so that inventory turnover becomes higher which leads to lower 
The 8th International Conference on Transportation \& Logistics (T-LOG 2020)

Surabaya September 6th-7th 2020, Universitas Internasional Semen Indonesia (UISI), Gresik, Indonesia

inventory costs. For transporters, shorter distribution time and smooth highway condition can reduce vehicle maintenance and fuel costs. However, there is a fact that the toll road has not been connected directly to the Panjang Port. This makes distribution activities from the production area to the port ineffective and inefficient. Nevertheless, the development of the highway has proven to be able to eliminate the surcharges that previously often arise on trips between Lampung and Palembang. The benefit of a toll road for consumers is the timeliness of goods receipt from producers. Based on this study findings, it can be developed the design of integrated logistics activities between producers and transporters in further reserach. Moreover, this study still has limitations, one of which only considers respondents from the producer, transport, and government side. Therefore, future research can also incorporate perceptions from suppliers to get a more comprehensive picture of the impact of highway construction on logistics costs.

\section{REFERENCES}

[1] P. Hayaloglu, "The Impact of Developments in the Logistics Sector on Economic Growth: The Case of OECD Countries,” Int. J. Econ. Financ. Issues, vol. 5, no. 2, pp. 523-530, 2015.

[2] X. Liu, "The impact of logistics costs on the economic development: The case of Thailand,” Bus. Public Adm. Stud., vol. 10, no. 1, pp. 3742, 2016.

[3] K. Sharipbekova and Z. Raimbekov, "Influence of logistics efficiency on economic growth of the CIS countries,” Eur. Res. Stud.
J., vol. 21, no. 2, pp. 678-690, 2018.

[4] R. Beysenbaev and Y. Dus, "Proposals for improving the Logistics Performance Index,” Asian J. Shipp. Logist., vol. 36, no. 1, pp. 34 42, 2020.

[5] B. Erkan, “The Importance and Determinants of Logistics Performance of Selected Countries,” J. Emerg. Issues Econ. Financ. Bank., vol. 3, no. 6, 2014.

[6] A. Gani, "The Logistics Performance Effect in International Trade," Asian J. Shipp. Logist., vol. 33, no. 4, pp. 279-288, 2017.

[7] Z. H. Munim and H.-J. Schramm, "The impacts of port infrastructure and logistics performance on economic growth: the mediating role of seaborne trade," J. Shipp. Trade, vol. 3, no. 1, p. 1, 2018.

[8] J.- Rodrigue, The Geography of Transport Systems, 4th ed. 2017.

[9] A. Banerjee, E. Duflo, and N. Qian, "On the road: Access to transportation infrastructure and economic growth in China,” J. Dev. Econ., vol. 145, 2020.

[10] C. Ferrari, A. Bottasso, M. Conti, and A. Tei, "The Economics of Transport Infrastructure,” Econ. Role Transp. Infrastruct., pp. 5-38, 2019.

[11] Y. R. Perdana, W. S. Ciptono, and S. Kusdhianto, "Broad span of supply chain integration: theory development,” Int. J. Retail \&amp; Distrib. Manag., vol. 47, no. 2, pp. 186-201, 2019.

[12] K. Kogan and C. S. Tapiero, "Investment and Supply Chain Infrastructure,” in IFAC Proceedings Volumes, 2006.

[13] J. Wessel, "Evaluating the transport-mode-specific trade effects of different transport infrastructure types," Transp. Policy, vol. 78, pp. 42-57, 2019.

[14] J. T. Mentzer and T. M. McCarthy-Byrne, "Integrating supply chain infrastructure and process to create joint value,” Int. J. Phys. Distrib. Logist. Manag., vol. 41, no. 2, pp. 135-161, 2011.

[15] J. Arnold, "The Role of Transport Infrastructure, Logistics, and Trade Facilitation in Asian Trade BT - Pan-Asian Integration: Linking East and South Asia.”

[16] J. Gonzalez, J. Guasch, and T. Serebrisky, "Improving logistics costs for transportation and trade facilitation,” 2008. 